\title{
Effect of Injection Timing on the Utilization of B20 Blends of Dairy Scum Oil Methyl Esters (Dsome) Fulled Diesel Engine
}

\author{
M. Nandeesh ${ }^{1}$, C. R. Rajashekar ${ }^{2}$, N. R. Banapurmath ${ }^{3 *}$ \\ ${ }^{1}$ Research Scholar, Sri Siddhartha Academy of Higher Education, Tumkur, INDIA \\ ${ }^{2}$ Department of Mechanical Engineering, MITE, Moodubidre, INDIA \\ ${ }^{3}$ School of Mechanical Engineering, BVB CET, KLE Technological University, Hubballi, INDIA
}

*Corresponding Author: nrbanapurmath@gmail.com

Citation: Nandeesh, M., Rajashekar, C. R. and Banapurmath, N. R. (2019). Effect of Injection Timing on the Utilization of B20 Blends of Dairy Scum Oil Methyl Esters (Dsome) Fulled Diesel Engine. European Journal of Sustainable Development Research, 3(2), em0082. https://doi.org/10.20897/ ejosdr/3971

Published: March 3, 2019

\begin{abstract}
Diesel engines are the prime movers that are highly efficient compared to their counter part of petrol engines. However, higher $\mathrm{NOx}$, particulate matter CO, HC are the draw backs associated with their operation. Renewable fuels like biodiesel and their blends are suitable and substitute for different applications as they are renewable in nature and provide satisfaction for fossil fuels of diesel which are exhaustible in nature and add burden to the Indian economy. In this direction the experiments were planned on the modified diesel engines to study the effects of Dairy scum oil methyl esters B20 blend (DSOME B20). By Advancing the time of injection from $19^{\circ}$ to $27^{\circ} \mathrm{BTDC}$, keeping injection opening pressure IOP constant results are obtained and analysed. It is noticed that higher BTE, lower emissions of smoke, HC, $\mathrm{CO}$ emissions while NOx increased.
\end{abstract}

Keywords: diesel engines, emissions, dairy scum biodiesel blends, combustion parameters

\section{INTRODUCTION}

Depleting nature and harmful exhaust emissions from power generation resulted in severe health hazards. Since fossil fuel are depleting in nature because the crude oil in the earth crust was reduced to 1.2 trillion barrels in 2011 compared to 2.4 trillion barrels during 1998. Further, the emission levels in the atmosphere led to various health hazards. In view of this, the present work has been taken to find substitute fuel to diesel. However, use of vegetable oils in engines leads to some operational and durability problems resulting poor performance and greater emission levels. Such problems can be minimized by converting vegetable oils in to their respective biodiesels. It is well known that greater viscosity, density, lower volatility and presence of heavy molecular weight fatty acids of vegetable oils are accountable for such results (Abed et al., 2018). Several investigators have studied the performance of biodiesel fuelled diesel engines. Greater fuel consumption with biodiesel operation has been reported (Qi et al., 2009; Buyukkaya, 2010; Bari et al., 2004) due to its more density, lower calorific value, which results in higher specific fuel consumption. In addition greater $\mathrm{HC}$ and $\mathrm{CO}$ emissions with increased load and decreased NOx emission levels for biodiesel operation have been reported. Some investigations highlighted that Biodiesels with blending ratio more than $40 \%$ decreases the thermal efficiency, and increases the exhaust gas temperature and emission levels (Shahabuddin et al., 2013). Further, the combustion parameters of diesel engine with biodiesel and blends operation has been investigated. Biodiesel operation leads to higher ignition delay, reduced cylinder pressure and heat release rate (Bari et al., 2004; Shahabuddin et al., 2013). Further, they noticed lower CO, HC, and PM exhaust emissions and increased NOx emission levels.Some studies used (Narsinga and 
Table 1. Properties of dairy scum biodiesel (DSOME)

\begin{tabular}{clllcl}
\hline S1. NO. & Properties & Diesel & DSOME & DSOME (B20) & ASTM standard \\
\hline 1 & Kinematic viscosity $\left(\mathrm{cSt}\right.$ at $\left.40^{\circ} \mathrm{C}\right)$ & 2.54 & 3.9 & 3.6 & ASTM D445 \\
\hline 2 & Flash point & 54 & 130 & 90 & ASTM D93 \\
\hline 3 & Caloric value $(\mathrm{kJ} / \mathrm{kg})$ & 43,500 & 39,940 & 40,550 & ASTM D5865 \\
\hline 4 & Density $\left(\mathrm{kg} / \mathrm{m}^{3}\right)$ & 830 & 870 & 815 & ASTM D4052 \\
\hline 5 & Cetane number & 50 & 52.8 & -- & ASTM D613 \\
\hline
\end{tabular}

Ranjith, 2017) blended nano particles with biodiesel and studied the effect of injection timing and injection pressure. By varying injection pressures from 200-240 bar and fuel injection timings from $19^{\circ}-27^{\circ}$ BTDC reported as pressure $240 \mathrm{bar}$ and timing $19^{\circ}$ BTDC will give better performance and reduced emissions. Studies with Ceiba Pentandra oil methyl ester (CPOME) as fuel in diesel engines shows that injection timing of $27^{\circ} \mathrm{C} \mathrm{BTDC}$, injection pressure of $240 \mathrm{bar}$ are optimum with 5 hole injector with improved performance and less emissions (Nagesh et al., 2017). While Experiments with simarouba biodiesel on diesel engine found better performance with retarded injection timings with substantial reduction in carbon monoxide emissions as compared to standard injection timing for diesel (Pai and Shettigara, 2016). Further, investigated that increasing the number of holes from three to four resulted with Honge biodiesel resulted in amplified brake thermal efficiency and decreased pollutants. They also focussed on induced swirl techniques to improve the mixing of air and fuel (Tumbal et al., 2016). Experiments conducted on diesel engines by varying injection timing with various biodiesel blends at different speeds highlights that the torque is increasing with injection advance for all the blends with decreasing specific fuel consumption (Rostami and Ghobadian, 2014). Investigations on single cylinder diesel engine with EGR at advanced Injection timing stated that higher peak pressure, longer delay period, higher maximum heat release rate and shorter combustion duration were observed than those at standard injection (Saravanan, 2015). The studies studied with waste cooking oil establish significant improvements in thermal efficiency, gas pressure and heat release rate at 280 bar injection pressure and injection timing of $25.51^{\circ} \mathrm{BTDC}$ ith reduction in NOx and smoke (Kannan and Anand, 2012). More over it was recommended that by advancing the injection timing the engine runs smoother at low load, speed conditions with increase in fuel consumptions for rape seed oil. The observed performance was comparable with neat diesel fuel (Nwafor and Rice, 2000). Experimental results on different biodiesel concluded, that B10, B20 have better brake thermal efficiencies slightly lesser than neat diesel with reduced emissions. The optimum injection timing with Jatropa as biodiesel was $20^{\circ}$ BTDC with less fuel consumption and maximum thermal efficiency, heat release rate (Venkateshwarrao and Rao, 2008). The experiments on diesel engine fuelled with methyl esters of mango seed oil with blend B25 by varying injection timing and concluded that $23^{\circ} \mathrm{bTDC}$ is the optimum injection timing and injection pressure which gives better performance, combustion and lower emissions when compared to other injection timings (Vijayaraj and Saravanan, 2017). The studies on algae oil methyl ester blend as a fuel for CI Engine with varying injection timing shows that advancing the injection timing by $30^{\circ}$ BTDC improves performance and emission characteristics significantly (Swamy and Ramesha, 2015).

From the literature it is observed that use of dairy scum oil derived from dairy milk waste is less investigated. Moreover, it is available freely and leads to land and water pollution if not disposed properly. In view of this experimental investigations were conducted on a four-stroke water cooled direct injection diesel engine operated on dairy scum biodiesel and its blends. Finally the results were compared with base line operation.

\section{CHARACTERIZATION OF FUELS USED}

In the current study Dairy Scum oil methyl ester (DSOME) derived from wastages of Dairy products is selected. The annual milk production is more than 150 million tonnes in India. In large dairies the residual butter and related fats get collected during washing in effluent treatment plants as a scum. Huge amount of milk when processed in a big dairy produces $210-340 \mathrm{~kg}$ of scum the disposal of which is problem. Scum is turbid white in colour. The scum is disposed in the form of semi solid in texture at the site. Scum extracted from the dairy and processed through transesterification process to obtain Dairy Scum Oil Methyl Ester (DSOME), which has similar properties as mineral diesel. In the present study the DSOME is used as an alternative fuel in the single cylinder diesel engine. The properties of DSOME shown in Table 1.

\section{EXPERIMENTAL SET UP}

Experiments were carried out on a single cylinder, four stroke, water cooled, compression ignition DI engine of $660 \mathrm{cc}$ capacity with compression ratio of 17.5:1. This engine is competent of rising $5.2 \mathrm{~kW}$ at a rated speed of $1500 \mathrm{rpm}$. Experimental set up and its specification shown in Figure 1 and Table 2 respectively. The tests were conducted to evaluate and compare performance, combustion and emission characteristics under diverse operating 




Figure 1. Schematic view of the experimental set up for single fuel operation

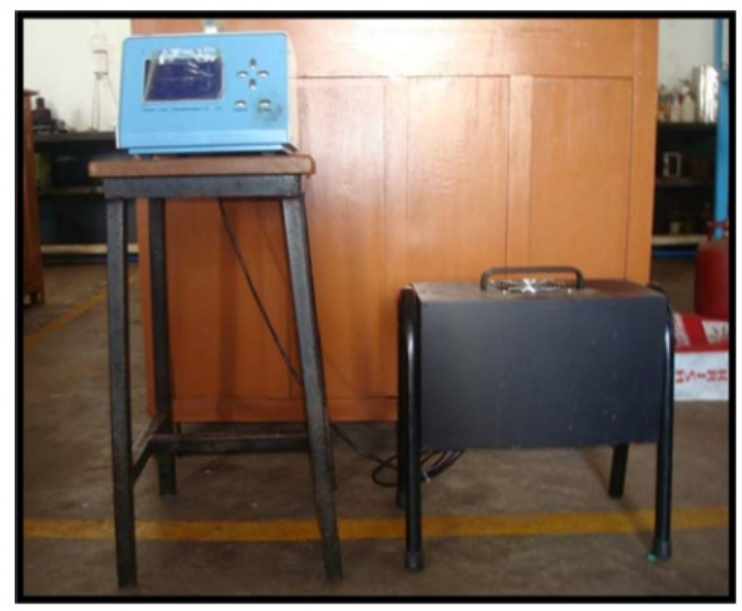

Figure 2. Smoke meter

conditions. The engine setup was coupled to the electrical dynamometer for applying load on the engine. The setup is furnished with sensors and instrumentation for recording various parameters such as cylinder pressure, speed, load, temperature, air and fuel flow rates. The engine soft ware is used to interface the data. The injector opening pressure (IOP) and the static injection timing (IT) was $205 \mathrm{bar}$ and $23^{\circ}$ Before Top Dead Centre (BTDC) respectively. The injection timings are varied through lift length of the rod in the mechanical fuel pump apart from the manufacturer recommended injection timing. The governor adopted controls the constant speed of the engine. The engine is provided with over head valves. A hemispherical bowl shape combustion chamber is provided in the piston head.The cylinder pressure of the engine is sensed by piezoelectric transducer mounted cylinder head surface suitably.

\section{Uncertainty Analysis of the Experimental Data}

The accuracy of the measurement and the uncertainty in the calculated parameters of the current investigation are provided in the Table 3. In order to minimize the errors of measurement four readings were recorded and averaged out results are presented for the analysis. 


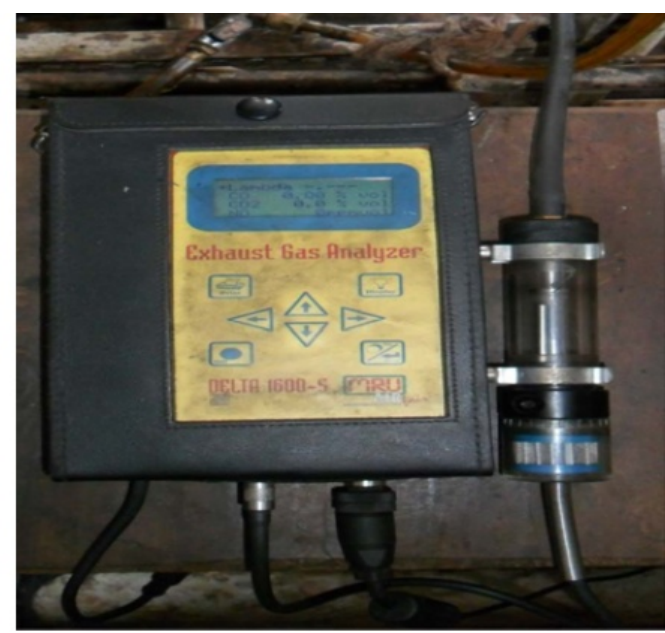

Figure 3. Exhaust Gas analyzer

Table 2. Engine specifications

\begin{tabular}{ll}
\hline Make & Kirloskar \\
\hline Model & TV1 \\
\hline Number of cylinders & Single \\
\hline Strokes & Four \\
\hline Method of injection & Direct injection, Mechanical type \\
\hline Orientation & Vertical \\
\hline Method of Ignition & Compression Ignition \\
\hline Arrangement of valves & Overhead \\
\hline Displacement cc & 660 \\
\hline Compression Ratio & $17.5: 1$ \\
\hline Bore mm & 87.5 \\
\hline Strokemm & 110 \\
\hline Combustion Chamber & Hemispherical type \\
\hline Rated Power & $5.2 \mathrm{~kW}(7 \mathrm{HP})$ at $1500 \mathrm{Rev}$ per min \\
\hline
\end{tabular}

Table 3. The accuracy of the measurement and the uncertainties in the calculated parameters

\begin{tabular}{ll}
\hline Measured variable & Accuracy $\mathbf{( \pm )}$ \\
\hline Load, $\mathrm{N}$ & 0.1 \\
\hline Engine speed, rpm & 1 \\
\hline Temperature, ${ }^{\circ} \mathrm{C}$ & 1 \\
\hline Fuel consumption, g & 0.1 \\
\hline HFFR, kg/h & 0.001 \\
\hline Measured variable & Uncertainty $\mathbf{( \% )}$ \\
\hline HC & \pm 1.2 \\
\hline CO & \pm 2.5 \\
\hline SOx & \pm 2.3 \\
\hline Calculated parameters & \pm 2.0 \\
\hline BTE $($ dual fuels, $\%)$ & Uncertainty $\mathbf{( \% )}$ \\
\hline HFER $(\%)$ & \pm 1.2 \\
\hline HRR $\left(\mathrm{J} /{ }^{\circ} \mathrm{CA}\right)$ & \pm 1.5 \\
\hline
\end{tabular}

\section{RESULTS AND DISCUSSIONS}

Initially the experiments were conducted on diesel engine fuelled with diesel and various blends of dairy scum (B10, B20, B30, B40, B50) biodiesel and the results are analyzed. By the analysis the Blend ratio of B20 (80\% diesel and $20 \%$ DSOME by volume) was found to be optimum. Hence the experiments were continued with B20 and the injection timing was varied to study the effect of injection timing with performance, emission and combustion characteristics. Prolonged use of biodiesel with higher blends, higher than B60 leads to more deposition of unburnt $\mathrm{HC}$ on the piston and cylinder heads, the nozzle hole gets clogged with carbon deposits etc. The fuel injection pressure was fixed at $205 \mathrm{bar}$ and the experiments were conducted by varying injection timings of $19^{\circ}, 23^{\circ}, 27^{\circ}$ and $31^{\circ} \mathrm{BTDC}$. The readings were noted when the operating conditions are stabilized. Keeping in view of readings with accuracy, the average of six readings are taken for each of the condition specified. 


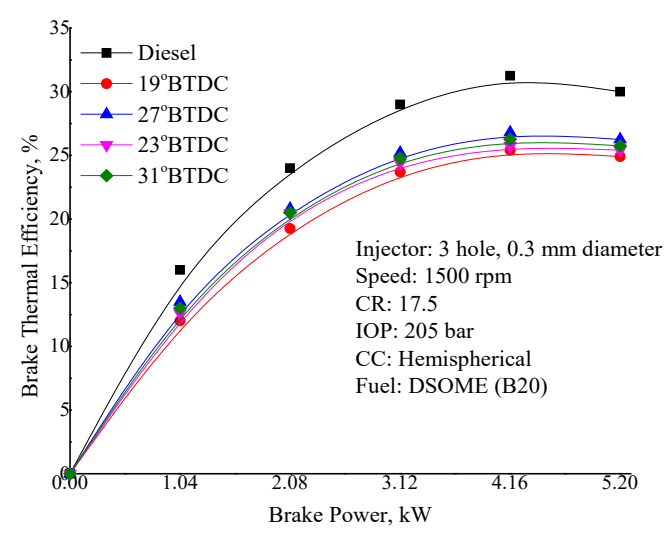

Figure 4. Effect of injection timing on Brake Thermal Efficiency

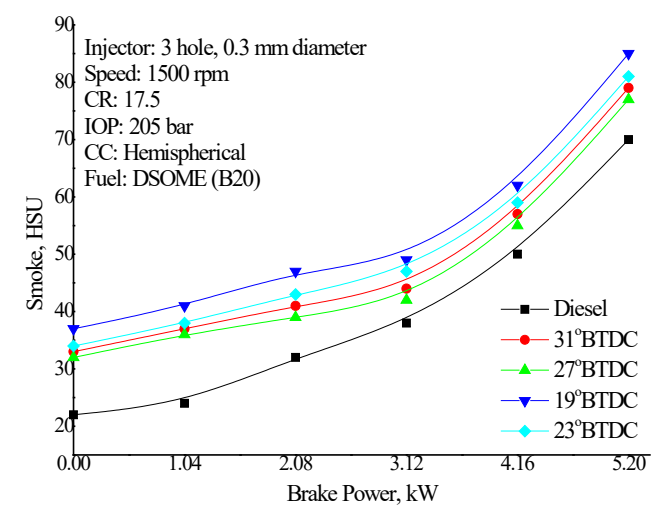

Figure 5. Effect of injection timing on Smoke opacity

\section{Effect of Injection Timing on Brake Power}

The outcome of injection timing on brake thermal efficiency for diesel, and DSOME (B20) at four injection timings is presented in Figure 4. It was noted that the Dairy scum biodiesel blend B20 shows lower efficiency than diesel for all the injection timing tested. This trend might be due to lower caloric value and higher fuel consumption of the biodiesel for the output specified. Further, this trend may also due to more viscous property of biodiesel and poor mixing of air and fuel which may result inefficient combustion compared to diesel fuel. The maximum brake thermal efficiency at $27^{\circ} \mathrm{BTDC}$ is $27.00 \%$ as compared to $31.25 \%$ for diesel. There was slight increase in brake thermal efficiency about $28.5 \%$ for B20 blend when the timing is advanced to $31^{\circ} \mathrm{bTDC}$. From the observations the optimum injection timing for neat diesel and DSOME B20 was selected as $23^{\circ} \mathrm{BTDC}$, and $27^{\circ} \mathrm{BTDC}$ respectively.

\section{Effect of Injection Timing on Smoke Opacity}

Figure 5 highlights outcome of injection timing on smoke emission for diesel, and DSOME (B20). From graph learnt that Smoke opacity for both fossil diesel and DSOME (B20) increased with increased brake power. It is noticed that smoke opacity is higher for DSOME (B20) as compared to diesel. This is due to higher molecules of particulate matter and hydrocarbons in the exhaust. As the injection time is advanced the smoke level is decreased for the DSOME (B20) and is minimum at the of $27^{\circ}$ BTDC. This indicates proper combustion of the fuel. By advancing the timing the delay period is long, decreases the temperature and pressure of fuel and major portion of fuel burns is pre mixed mode. This could finally results in lower smoke levels. Further, advancing to $31^{\circ}$ BTDC the brake thermal efficiency is decreased with increased fuel consumption. This leads to increase in smoke level. The smoke level is minimum for DSOME (B20) at $27^{\circ}$ BTDC as shown in Figure 5. The smoke values were found to be $62 \mathrm{HSU}, 59 \mathrm{HSU}, 55 \mathrm{HSU}$ and $57 \mathrm{HSU}$ at the injection timings of $19^{\circ}, 23^{\circ}, 27^{\circ}$ and $31^{\circ} \mathrm{BTDC}$ respectively at $80 \%$ load. 




Figure 6. Effect of injection timing on Unburned Hydrocarbon Emissions



Figure 7. Effect of injection timing on Carbon Monoxide Emissions

\section{Effect of Injection Timing on HC}

Figure 6 shows the consequence of injection timing on HC and CO emissions for diesel and DSOME (B20). As the load on the engine increases the smoke opacity from the engine increases gradually. HC emissions from diesel engines mainly owing to incomplete combustion and the various factors which influence the combustion inside the cylinder are overlean mixture, over rich mixture, improper flame propagation, bulk quenching of cylinder wall, fuel injected at injector orifice at reduced velocity at the end of injection period may result in UBHC.The observations highlight the increasing trend of HC emissions for the DSOME (B20) with retarding the injection timing at $80 \%$ load. This may attributes to decrease in efficiency with respect to combustion for DSOME B20. The best injection timing was found to be $27^{\circ}$ BTDC for biodiesel. The HC values are found to be $51 \mathrm{ppm}, 47$ ppm, 43 ppm, $45 \mathrm{ppm}$ for $19^{\circ}, 23^{\circ}, 27^{\circ}$ and $31^{\circ}$ BTDC.

\section{Effect of Injection Timing on CO}

Carbon monoxide is a poisonous derivative obtained from the combustion process and is a clear sign of partial combustion within the engine cylinder. From the results it is found that the magnitude of CO is lower at advanced injection timing and higher at retarded injection timing for all the injection timings tested. DSOME (B20) blend showed somewhat higher $\mathrm{CO}$ emissions for the similar reasons explained in $\mathrm{HC}$ emissions. The $\mathrm{CO}$ values at full load $0.28 \%, 0.26 \%, 0.22 \%, 0.24 \%$ for the injection timings of $19^{\circ}, 23^{\circ}, 27^{\circ}$ and $31^{\circ} \mathrm{BTDC}$ for DSOME (B20) fuel whereas for the diesel it is $0.2 \%$ for the standard injection timing. The optimum injection timing of $27^{\circ} \mathrm{BTDC}$ for DSOME B20 records the lowest CO levels which shows improved combustion as injection timing is delayed. 


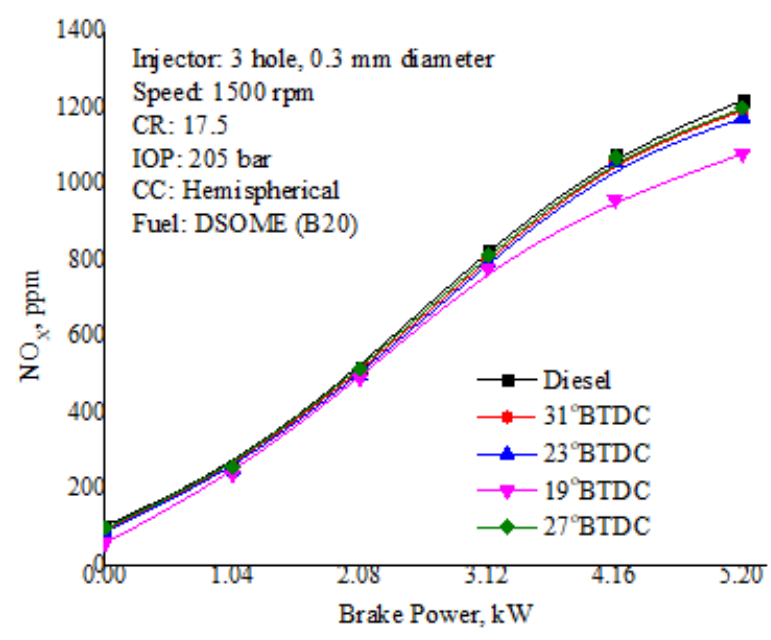

Figure 8. Effect of injection timing on NOx Emissions



Figure 9. Effect of injection timing on Peak Pressure

\section{Effect of Injection Timing on NOx}

The result of injection timing on the formation of NOx with brake power for diesel, DSOME (B20) is shown in Figure 8 Higher brake thermal efficiency is observed with diesel and the related speedy combustion phase could be reason for the observed increase in NOx trends. This attributes to higher peak temperature, availability of oxygen and residual time of gases. Further, the retarded injection timing reduces NOx noticeably. As the injection timing is retarded the combustion phase is retarded which reduces the peak temperature in the cycle. Formation of NOx is less with lower peak temperatures. It is noticed for the DSOME (B20) blend as injection advances further to $31^{\circ} \mathrm{BTDC}$, the NOx level increases due longer delay period associated with sharp pre-mixed heat release rate. From the results it was concluded that the optimum injection timing for DSOME (B20) is $27^{\circ}$ BTDC (static) at which the brake thermal efficiency is higher while the smoke, $\mathrm{CO}, \mathrm{HC}$ emissions are lower.

\section{Effect of Injection Timing on Peak Pressure}

The effect of injection timing on peak pressure with brake power for diesel and DSOME (B20) operation is presented in graph 9. Results revealed that at retarded injection timing lowers the peak pressure rise for DSOME (B20) than diesel due to shorter ignition delay, slow burning, higher ignition temperature, lower adiabatic temperature at all the injection timings tested. This attributes to higher viscosity and poor atomization and incomplete combustion of the biodiesel.The engine operation was smoother, noiseless when the injection time is retarded due to lower peak pressure and less temperature. Further, the advanced injection timing tends to increase the delay period results in higher peak pressure for DSOME (B20) fuel. The auto ignition temperature and rapid combustion results in for sharp increase in pressure for neat diesel. The peak cylinder pressure of 78 bar was noted 


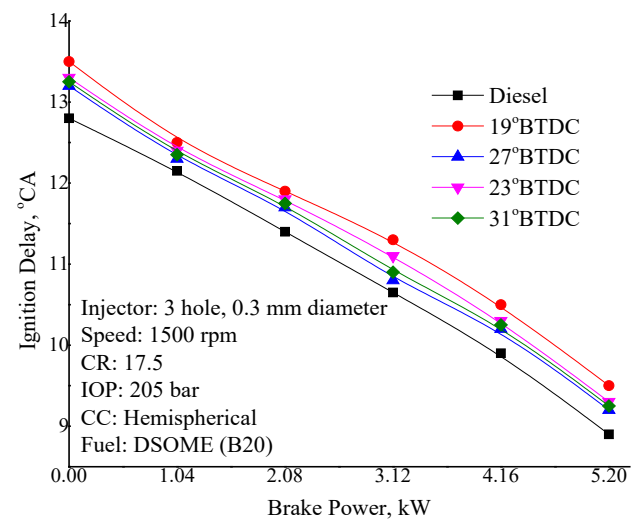

Figure 10. Effect of injection timing on Ignition Delay Period

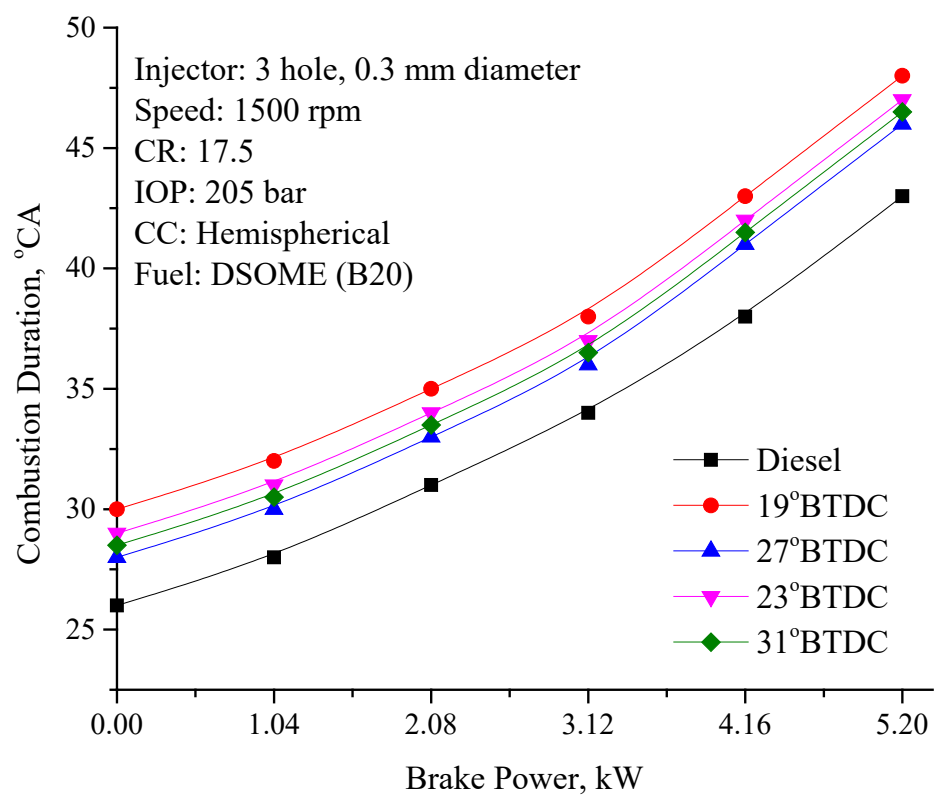

Figure 11. Effect of injection timing on Combustion duration

at the injection timing of $27^{\circ} \mathrm{BTDC}$ when the engine is running with full load for DSOME B20 compared to neat diesel with peak pressure of 84 bar.

\section{Effect of Injection Timing on Ignition delay}

Figure 10 correlates the injection timing, ignition delay with brake power. From the observations it was learnt that as the load on the engine raises the delay period show lower trend for all the fuels tested. The ignition delay is lower for neat diesel, higher for DSOME (B20) fuel and increases with higher blends of biodiesel. With the advanced injection time ignition delay decreases. This could be attributes to improved combustion of fuel and brake thermal efficiency.

\section{Effect of Injection Timing on Combustion Duration}

The behavior of combustionduration with injection timing and brake power is revealed in Figure 11. From the results it is observed that the combustion duration is decreasing as the load on the engine increases. The retarded injection timing for DSOME B20 increases the combustion duration. Further, advancing the injection timing reduces the combustion duration and the lowest combustion duration is noticed for B20 blend with injection timing $27^{\circ}$ BTDC which is still higher than neat diesel. This may be due to higher viscosity, improper air and fuel ratio, poor atomization of biodiesel fuel with longer diffusion combustion phase. 


\section{CONCLUSION}

From the experimental investigations carried out to check the feasibility of utilization of B20 DSOME with various injection timings the following conclusions were made

1. B20 blend of DSOME can be used as an alternative to the diesel fuel.The performance of B20 DSOME inferior compared to fossil fuel. However, with advanced injection timing the performance was improved and was comparable to conventional diesel fuel operation

2. Advancing the injection timing from $19^{\circ}$ to $27^{\circ}$ BTDC the brake thermal efficiency increased by $5.14 \%$

3. Further, advancing the injection timing from $19^{\circ}$ to $27^{\circ}$ BTDC Smoke reduced by $11 \%$, HC reduced by $17 \%$, CO reduced by $20 \%$

4. However, the NOx emission increased by $1.6 \%$ when injection timing IT was varied from $19^{\circ}$ to $27^{\circ}$ BTDC. The NOx emission can be reduced with appropriate techniques like EGR etc.

\section{REFERENCES}

Abed, K. A., El Morsi, A. K., Sayed, M. M., El Shaib, A. A. and Gad, M. S. (2018). Effect of waste cooking-oil biodiesel on performance and exhaust emissions of a diesel engine. Egyptian Journal of Petroleum.

Bari, S., Yu, C. W. and Lim, T. H. (2004). Effect of fuel injection timing with waste cooking oil as a fuel in a direct injection diesel engine. Proc Inst Mech Eng, Part D: J Auto Eng, 218(1), 93-104. https://doi.org/10.1243/095440704322829209

Buyukkaya, E. (2010). Effects of biodiesel on a DI diesel engine performance, emission and combustion characteristics. Fuel, 89(10), 3099-3105. https:// doi.org/10.1016/j.fuel.2010.05.034

Ganapathy, T., Gakkhar, R. P. and Murugesan, K. (2011). Influence of injection timing on performance, combustion and emission characteristics of Jatropha biodiesel engine. Appl. Energy, 88(12), 4376-86. https://doi.org/10.1016/j.apenergy.2011.05.016

Kannan, G. R. and Anand, R. (2012). Effect of injection pressure and injection timing on DI diesel engine fuelled with biodiesel from waste cooking oil. Biomass and Bio energy, 46, 343-352. https://doi.org/10.1016/j.biombioe.2012.08.006

Nagesh, S. B., Chandrashekhar, T. K. and Banapurmath, N. R. (2017). Effect of Injection Timing and Injector opening pressures on the Performance of diesel engine fuelled with Ceiba Pentandra Oil Methyl Ester. Recent Adv Petrochem Sci, 1(3), 555-564. https://doi.org/10.19080/RAPSCI.2017.01.555564

Narsinga, R. and Ranjith, K. S. (2017). Effect of Fuel Injection Pressure and Injection Timing on Performance and Emissions of Diesel Engine Using Nanoadditive Blends. RRJASI, 1(4).

Nwafor, O. M. I. and Rice. (2000). Effect of Advanced injection timing on the performance of rape seed oil in diesel engines. Renewable energy Elsevier, 21(3), 433-444.

Pai, S. and Shettigara, A. (2016). Effect of Injection Timing on Performance and Emission of a Direct Injection Diesel Engine Fueled with Simarouba Biodiesel blend. National Conference on Advances in Mechanical Engineering Science (NCAMES-2016).

Qi, D. H., Geng, L. M., Chen, H., Bian, Y. Z. H., Ch, X. and Ren, J. L. (2009). Combustion and performance evaluation of a diesel engine fuelled with biodiesel produced from soybean crude oil. Renewable Energy, 34(12), 2706-2713. https://doi.org/10.1016/j.renene.2009.05.004

Rostami, S. and Ghobadian, B. (2014). Effect of the Injection Timing on the Performance of a Diesel Engine Using Diesel-Biodiesel Blends. IJAME, ISSN: 2180-1606 (Online), 10, 1945-1958.

Saravanan, S. (2015). Effect of EGR at advanced IT on combustion characteristics of diesel engine. AEJ, 54, 339342.

Shahabuddin, M., Liaquat, A. M., Masjuki, H. H., Kalam, M. A. and Mofijur, M. (2013). Ignition delay, combustion and emission characteristics of diesel engine fuelled with biodiesel. Renewable and Sustainable Energy Reviews, 21, 623-632. https://doi.org/10.1016/j.rser.2013.01.019

Swamy, K. M. and Ramesha, D. K. (2015). The effect of injection pressure and injection timing on performance and emission parameters with algae oil methyl ester blend as a fuel for CI engine. International Journal of Scientific and Research, 5(11), 210- 215.

Tumbal, A. V., Banapurmath, N. R. and Tewari, P. G. (2016). Effect of injection timing, injector opening pressure, injector nozzle geometry, and swirl on the performance of a direct injection, compression-ignition engine fuelled with honge oil methyl ester (HOME). International Journal of Automotive Technology, 17(1), 35-50. https://doi.org/10.1007/s12239-016-0003-3 
Venkateshwarrao, T. and Rao, G. P. (2008). Experimental investigation of Pongamia, jatropha and neem methyl esters as biodiesel on CI engines. JJMIE, 2, 117-122.

Vijayaraj, K. and Saravanan, C. G. (2017). Experimental Investigation for Various Injection Pressure and Injection Timing of a Diesel Engine using B25 Methyl Ester of Mango Seed Oil. 9(1), 31-44. 